\title{
About the Comparative and Qu'ranic Analysis of cdots in Nigeria
}

\author{
Uthman ibn Afaq
}

ABSTRACT: It is written that The paper examines and compares the performance of the agricultural sector during the Military and the Civilian Regimes in Nigeria. It also compares the proportion of public expenditures on agriculture with the allocations to other sectors of the economy such as Education, Health and Transport. The paper adopts a descriptive approach and the findings show that there is a direct relationship between the proportion of public expenditure and agricultural performance and that public expenditure on the Agricultural Sector lags behind the expenditures on these other sectors. The paper also shows that the Agricultural Sector received more percentage of public expenditure during the Civilian regime but the contribution of agriculture to Gross Domestic Product (GDP) was higher during the Military than the Civilian regime. This shows that the performance of agriculture is not only a function of the proportion of public expenditure, but a combination of factors such as judicious use of the resources, the quality of agricultural policies/programmes embarked upon, among others. The paper therefore recommends increased budgetary allocation to the Agricultural Sector as well as its proper and judicious use to guarantee poverty reduction, sustainable livelihood and enhanced food security.

\section{REFERENCES}

[1]. Schunk, D. H., \& DiBenedetto, M. K. (2020). Motivation and social cognitive theory. Contemporary Educational Psychology, 60, 101832.

[2]. Dorfman, B. S., \& Fortus, D. (2019). Students' self-efficacy for science in different school systems. Journal of Research in Science Teaching, 56(8), 1037-1059.

[3]. Brew, E. (2019). Determinants of low performance of female students In science subject: a survey of junior high schools in the Aowin district (Doctoral dissertation, University of Cape coast).

[4]. Falco, L. D., \& Summers, J. J. (2019). Social Persuasions in Math and Their Prediction of STEM Courses Self-Efficacy in Middle School. The Journal of Experimental Education, 1-18

[5]. Ntarmah, A. H., Gyan, M. K., Gyedu, S., \& Cobbinah, E. The Predictive Power of Sources of Teacher Efficacy beliefs on Economics Teachers' Efficacy beliefs in the Implementation of Senior High School Economics Curriculum.

[6]. McBride, E., Oswald, W. W., Beck, L. A., \& Vashlishan Murray, A. (2019). "I'm just not that great at science": Science self-efficacy in arts and communication students. Journal of Research in Science Teaching.

[7]. Deel, C. M. (2019). Causal-Comparative Study of Reading Self-Efficacy of Senior High School Students Based on English Course Placement.

[8]. Probst, J. R. (2019). A Causal-Comparative Analysis of Mathematics Self-Efficacy Based on Gender and Math Acceleration.

[9]. La Ode Ahmad Jazuli, E. S., \& Syahrial, Z. The Effect of Brain Based Learning Strategies and Project Based Learning on Mathematics Learning Outcomes in Students of the Kinesthetic Learning Style Group.

[10]. Pei-Boon, O., Wan Jaafar, W. M., Chin-Siang, A., \& Nee-Nee, C. (2020). Psychometric Properties of the Sources of Counseling Self Efficacy in a Sample of Malaysian Secondary School Counselors. SAGE Open, 10(1), 2158244020902076.

[11]. Hiroki, T. (2019). The Mathematical Expressions of Quranic Exegeses and the Mathematical Definition of the Quranic Correctness.

[12]. Hiroki, T. (2019). Methodology to Prove the Quranic Correctness. International Journal of Humanities and Social Science Invention, $8(10), 01-02$.

[13]. ibn Afaq, U. A Comparative Study of the Qu'ranic Correctness Claims between Wahid and Tahara.

[14]. ibn Afaq, U. About Unsteady Magnetopolar free Convection flow cdots in a Slip flow Regime.

[15]. ibn Afaq, U. About the Qu'ranic Study of cdots Naidu's Poetry. 